\title{
SOCIAL MOVEMENTS, SOCIAL PROBLEMS AND SOCIAL CHANGE
}

\author{
Ajay Kumar Yadav \\ Department of Sociology, TU,Thakur Ram Multiple Campus, Birgunj, Nepal
}

\begin{abstract}
Social movement is an organized effort by a significant number of people to change (or resist change in) some major aspect or aspects of society. Sociologists have usually been concerned to study the origins of such movements, their sources of recruitment, organizational dynamics, and their impact upon society. Social movements must be distinguished from collective behavior. Social movements are purposeful and organized; collective behavior is random and chaotic. Social movements include those supporting civil rights, gay rights, tade unionism, environmentalism, and feminism. Collective behaviors include riots, fads and crazes, panics, cultic religions, rumors. This paper deals with formation of social movement, emergence of social movement, social problems and social change.
\end{abstract}

\section{Key words}

Democracy; new social movements; panics; rights; rumors

\section{Introduction}

Social movement is one of the major forms of collective behavior. The term was first used by Saint-Simon in France at the turn of the eighteenth century, to characterize the movements of social protest that emerged there and later elsewhere, and was applied to new political forces opposed to the status quo. Nowadays, it is used most commonly with reference to groups and organizations outside the mainstream of the political system. These movements, often now abbreviated to NSMs (New Social Movements), have in the latter decades of the twentieth century become an increasingly important source of political change. In the recent years the study of social movements has attracted the attention of a large number of sociologists in Nepal, as well as in West. We hear of various kinds of social movements launched for one or the other purpose. There are movements to demand more and more reservation for the SCs and STs and other backward classes and there are counter movements demanding its cancellation or at least the status quo. There are movements to "save environment", to "save world peace ". There are movements for and against the construction of Temple 
at the disputed different places. There are Fascist Movements, Communist Movements, Naxalite Movements, Tribal Movements, Peasants' Movements, Women's Movements, Youth Movements, Labor Movements, Civil Rights Movements, Human Rights Movements, Afforestation Movements, and so on. A social movement is collective effort to promote or resist change (Horton \& Hunt, 1968).

Social movements include two characteristics about which there is considerable agreement among the sociologists which are as follows:

Collective action - Social movement undoubtedly involves collective action. However, this collective action, takes the form of a movement only when it is sustained for a long time. This collective action need not be formally organized. It could be an informal attempt also. But it should be able to create an interest and awakening in relatively large number of people.

Oriented towards social change - Social movement is generally oriented towards bringing about social change. This change could either be partial or total. Though the movement is aimed at bringing about a change in the values, norms, ideologies of the existing system, efforts are also made by some other forces to resist the changes and to maintain the status quo. The counter attempts are normally defensive and restorative rather than innovative and initiating change. They are normally the organized efforts of an already established order to maintain itself.

\section{Stages of social movement}

Social movement involves a few stages in its formation which are described in the paragraph below;

The preliminary stage -This stage can also be called the unrest stage. In this stage we find some confusion or discontentment among people. Hence they are restless. In fact, all social movements begin with some feeling of discontent with the existing social order. Discontent is always a product of a relationship between objective conditions and ideas about those conditions. If all the members in a society feel satisfied about everything, there is no chance for any social movement to emerge. The very presence of a movement indicates that people are dissatisfied with something or the other.

The popular stage - In the popular stage the movement begins to rally around a figure or a leader who promises to alleviate the sufferings of the people. This leader may be a charismatic leader with some extraordinary qualities who is capable of giving a leadership to the movement. He may speak of reform, revolution, resistance or express himself in such a way that the followers are made to feel that he will do something or the other to find solution to their problem. If the message of the leader is appropriate and very much appealing people would definitely rally around him.

The formalization stage - This is the stage in which programs are developed, alliances are forged, and organizations and tactics are developed. In this stage, a party, organization, or group of individuals may put forward an alternative vision, world-view or ideology, to understand analyses and solve a prevailing crisis. Once the ideology gains acceptance among people, effort must be made to translate it into a program which calls for collective action. This leads to the birth of the movement (Frank, 1987).

The stage of institutionalization of the movement - If the movement becomes successful, then it destroys itself in its last stage of development when it becomes an institution. At this point, it is no longer collective, behavior, because it is organized, follows accepted norms of society, and has replaced its emotional base with the assumption that change will take time (Wallace, 1956). 


\section{Theory of social movement}

There are three main theories concerning the emergence of social movements. They are: The relative deprivation theory, the strain theory and the revitalization theory.

The relative deprivation theory - Relative deprivation is a concept which explains that one feels deprived according to gap between expectations and realizations. The person who wants little and has little, feels less deprived than the one who has much but expects still more (Horton \& Hunt, 1968).

The strain theory - The strain theory of social movement has been propounded by Smelser (1993).This theory considers structural strain as the underlying factor contributing to collective behavior. Structural strain may occur at different levels such as norms, values, mobility, situational facilities, etc. Because of these structural strains some generalized belief that seeks to provide an explanation for the strain, may emerge. Both strain and generalized belief require precipitating factors to trigger off a movement. Smeller's analysis of the genesis of social movements is very much within the structural functional framework.

The theory of revitalization - The relative deprivation theory and the strain theory give us impression that social movements necessarily arise out of negative conditions such as deprivations and strain .In this context, Wallace (1956) has asserted that social movements develop out of a deliberate, organized and conscious effort on the part of members of a society to construct a more satisfying culture for themselves.

\section{Social movements and social problems}

Social movements play a very important role in highlighting some of the social problems. Some undesirable conditions can exist foryears or even centuries before they are recognized as social problems. Slavery, the subordination of women, untouchability, racial discrimination, communalism, poverty, inequality, pollution etc., were all generally regarded as either as natural or inevitable, or, as less important, until social movements drew the attention of the public, mobilized public opinion and campaigned for change. The degree of success of a social movement determines not only how the social problem is confronted but also what happens to the movement itself. The interplay of social problems and social movements produces a typical "life cycle" or "natural history" that often ends with the disappearance of the movement.

\section{Social movements and social change}

Social movements do not necessarily bring solutions to the social problems. They may champion the cause of social problems but cannot always promise a lasting solution. Social movements may promise to bring about social change and they do bring it. But it is not a one way process. Not only do social movements bring about change, but social change sometimes gives birth to movements. Social change often breeds social movements, and movements, in turn, breed additional change. In fact, Smeler has defined a social movement as an organized group effort to generate socio-cultural change (Rao, 2006).

Change is the law of nature. What is today shall be different from what it would be tomorrow. The social structure is subject to incessant change. Forty years hence government is due to make important changes. Family and religion will not remain the same during this period because these institutions are changing. Individuals may strive for stability, societies may create the illusion of permanence, the quest for certainly may continue unabated, yet the fact remains that society is an ever changing phenomenon, growing, decaying, renewing and accommodating itself to changing conditions and suffering vast modifications in the course of time. Our understanding of it will not be 
complete unless we take into consideration this changeable nature of society, study how differences emerge and discover the direction of change. Our direct concern as sociologists is with social relationships. It is the change in these relations which alone we shall regard as social change (Mac Iver \& Page, 1959).

\section{Conclusion}

Society is not a static element. It is a complex system of movements and counter movements pulling it in different directions. When this tussle is finally in favor of the movement, it becomes part of the social structure. A successful movement may become a part of the social order such as a trade union movement or save environment movement. The movement may disappear after achieving its goal.

It may be concluded that social change refers to the modifications, which take place in the life patterns of people. It does not refer to all the changes going in the society. The changes in art, language, technology, philosophy etc., may not be included in the term social change which should be interpreted in a narrow sense to mean alterations in the field of social relationships. Social relationships are social processes, social patterns and social interactions. Thus, social change means variations of any aspect of social processes, social patterns, interactions or social organization. It is change in an institutional and normative structure of society.

\section{References}

Bhusan, V. \& Sachdeva, D.R. (2002). An introduction to sociology. New Delhi: Kitab Mahal.

David, J. \& Tulia, J. (1995). Collins dictionary of sociology ( $2^{\text {nd }}$ ed.). New York: Harper Collins Publisher.

Frank, G. (1987). Crisis in the Third World. London: Hein Mann.

Horton, P. \& Hunt, C. (1968). Sociology. New York: Mc Graw Hill.

Mac Iver, R. M. \& Page, C. H. (1959). Society: An introductory analysis. London: Macmillan.

Rao, C. N. Shankar. (2006). Introduction to sociology. New Delhi: S.Chand and Company Ltd.

Smelser Neil. J. (1993). Sociology: An introduction. New Delhi: Wiley Eastern private Ltd.

Wallace, G. (1956). The great society. London: MacMillan. 